\title{
LEGALITAS PENGGUNAAN RAHIM IBU PENGGANTI (SURROGATE MOTHER) DALAM PROGRAMBAYI TABUNG DI INDONESIA
}

\author{
Oleh : \\ Rosida Diani \\ (Dosen Fakultas Hukum Universitas Tamansiswa Palembang) \\ Email : diani.sumadi2935@gmail.com
}

\begin{abstract}
Abstrak
Hukum ada untuk mengatur hidup masyarakat. Hukum kerap tertinggal dari perubahan yang terjadi di masyarakat. Perubahan teknologi salah satu hal yang membuat hukum tertinggal dari perubahan di masyarakat. Salah satu perkembangan teknologi yang membutuhkan pengaturan adalah mengenai penggunaan rahim perempuan lain (surrogate mother) pada program bayi tabung. penelitian ini merupakan penelitian hukum normatif dengan data yang digunakan data sekunder. Dari hasil penelitian didapatkan bahwa program bayi tabung sepanjang sperma dan ovum dari pasangan suami isteri dan embrio hasil pembuahan ditanamkan ke rahim isteri pemilik ovum maka hal tersebut diperbolehkan oleh hukum positif di Indonesia yaitu diatur di dalam UU No. 36 Tahun 2009 tentang Kesehatan dan Peraturan Pemerintah No 61 Tahun 2014 tentang Kesehatan Reproduksi. Sedangkan untuk penggunaan rahim perempuan lain, dengan melakukan penafsiran pasal 127 UU No. 36 Tahun 2009, dan Pasal 40 PP No 61 Tahun 2014 merupakan hal yang dilarang dalam hkum positif di Indonesia. Apabila ada pasangan suami isteri yang menggunaan rahim perempuan lain dalam bayi tabung maka yang akan dikenakan sanksi adalah tenaga medis dan fasilitas kesehatan yang melaksanakannya, bukan suami isteri pemilik sperma dan ovum dan bukan juga perempuan yang rahimnya disewa digunakan. Sanksinya berupa sanksi administrasi.
\end{abstract}

Kata kunci : rahim ibu pengganti

\section{A. Pendahuluan}

Anak mempunyai peranan yang penting dalam kehidupan sebuah keluarga, karena salah satu tujuan sepasang suami istri menikah adalah untuk memperoleh keturunan. Dalam pandangan agama Islam salah satu tujuan perkawinan adalah untuk memenuhi perintah Allah SWT agar memperoleh keturunan yang sah. ${ }^{1}$ Sehingga tidak heran jika banyak pasangan suami istri yang baru melangsungkan perkawinannnya mendambakan kehadiran seorang anak dalam kehidupan rumah tangganya. Namun tidak semua pasangan suami istri yang dapat dengan mudah mewujudkan keinginannya tersebut. Ada beberapa faktor penghambat

1 Hilman Hadikusuma, Hukum Perkawinan Indonesia menurut Perundangan, hukum adat, hukum agama, Mandar Maju, Bandung, 2007, hlm.127 
sehingga menyebabkan pasangan suami istri belum dapat mewujudkan mimpinya memperoleh keturunan

Ada beberapa faktor kesehatan yang menyebabkan belum hadirnya buah hati dalam suatu perkawinan. Keadaan suami istri tidak dikaruniai keturunan dalam dunia kesehatan disebut infertil. Penyebab infertilitas ini kira-kira 40\% karena kelainan pada pria, $15 \%$ karena kelainan pada leher rahim, 10\% karena kelainan pada rahim, 30\% karena kelainan pada saluran telur dan kelainan pada peritoneal, $20 \%$ karena kelainan pada ovarium, dan 5\% karena hal lain, dan kejadian totalnya melebihi $100 \%$, pada kira-kira $35 \%$ pada suami istri terdapat kelainan yang multiple. ${ }^{2}$

Sebagai hasil dari perkembangan dan kemajuan teknologi, membawa pengaruh pada ilmu kedokteran. Sebagian penyebab infertilitas tersebut dapat diatasi dengan pengobatan maupun operasi, sedang infertilitas yang disebabkan oleh kegagalan inseminasi, pembuahan, fertilisasi, kehamilan, persalinan, dan kellahiran hidup normal, ternyata dapat diatasi dengan cara buatan (artificial). Cara-cara tersebut antara lain : inseminasi buatan (artificalinsemination/AI), pembuahan dalam (artifical conception/AC), penyuburan/pembuahan dalam tabung (invitro fertilization/IVF), pemindahan janin/ penanaman janin (embriyo transferiembriyo transpalant/ET). ${ }^{3}$

Dalam in vitro fertilization atau fertiliasi in vitro atau lebih di kenal dengan bayi tabung. Fertilisasi in vitro atau bayi tabung adalah pembuahan sel telur oleh sel sperma di dalam tabung vetri yang dilakukan petugas medis. ${ }^{4}$ Kehadiran bayi tabung tidaklah menjadi permasalahan pada saat sperma dan sel telur berasal dari pasangan suami istri yang sah dan di masukan ke dalam rahim istri pemilik sel telur. Namun akan menjadi permasalahan kompleks

\footnotetext{
2 Idries, AM, Aspek Medikolegal Pada Inseminasi Buatan/Bayi Tabung, Ed.I, Jakarta, Binarupa Aksara.

${ }^{4}$ Husni Thamrin, Aspek Hukum Bayi Tabung dan Sewa Rahim : Perspektif Hukum Perdata dan Hukum Islam, Aswaja Pressindo, Yogyakarta, 2014, hlm.3
} 
saat embrio hasil fertilisasi in vitro di tanam ke rahim perempuan lain bukan rahim istri pemilik sel telur atau dikenal dengan surrogate mother. Berdasarkan hal tersebut maka di dalam tulisan ini akan dibahas mengenai legalitas penyewaan rahim ( surrogate mother) dalam kajian hukum Positif di Indonesia.

\section{B. Metode penelitian}

Penelitian hukum yang digunakan yaitu penelitian hukum normatif. Penelitian hukum normatif adalh penelitian hukum yang meletakkan hukum sebagai sebuah bangungan sistem norma. Sistem norma yang dimaksud adalah mengenai asas-asas, norma, kaidah dari peraturan perundang-undangan, putusan pengadilan, perjanjian sera doktrin (ajaran). ${ }^{5}$

Sumber data yang digunakan adalah data sekunder berupa bahan hukum primer seperti UU No.1 Tahun 1974 tentang Perkawinan, UU No.36 Tahun 2009 tentang Kesehatan. Peraturan Pemerintah No 61 Tahun 2014 Tahun Kesehatan, Kitab Undang-Undang Hukum Perdata. Dalam penelitian ini juga digunakan bahan hukum sekunder berupa literatur dan penelitian-penelitian yang membahas mengenai bayi tabung, khususnya mengenai kontrak rahim.

\section{Pembahasan}

Teknologi bayi tabung pertama kali berhasil dilakukan pada tahun 1978 di Oldham Inggris. ${ }^{6}$ Di Indonesia sendiri, keberhasilan program bayi tabung pertama kali pada tahun 1988 yaitu pada pasangan suami isteri Markus dan Chai Ai Lian. ${ }^{7}$

\footnotetext{
5 Mukti Fajar ND dan Yulianto Achmand, Dualisme Penelitian Hukum Normatif dan Empiris, Yogyakarta; Pustaka Pelajar, 2013, hal. 34

${ }^{6}$ PC. Steptoe dan R.G. Edwards, Birth After Reimplantation of Human Embryo, The Lancet, Vol II For 197 8, August 12, 1978, hlm. 366

${ }^{7}$ http://bayitabung-rsiafamily.com, diakses pada 28 Mei 2020
} 
John C. Fletcher membagi jenis bayi tabung (fertilisasi in vitro) menjadi dua macam yaitu $:^{8}$

1. In vitro (outside the human body) fertilization (IVF) using sperm of husband or donor

2. Egg of wife or surrogate mother.

Jika ditinjau dari sperma dan ovum serta tempat embrio yang ditransplantasikan, maka bayi tabung dibagi menjadi 8 (delapan) jenis yaitu: ${ }^{9}$

a. Bayi tabung yang menggunakan sperma dan ovum dari pasangan suami isteri yang kemudian embrionya ditransplantasikan ke dalam rahim isteri;

b. Bayi tabung yang menggunakan sperma dan ovum dari dari pasangan suami isteri yang kemudian embrionya ditransplantasikan ke dalam rahim ibu pengganti (surrogate mother);

c. Bayi tabung yang menggunakan sperma dari suami dan ovum dari donor, lalu embrionya ditransplantasikan ke dalam rahim isteri;

d. Bayi tabung yang menggunakan sperma dari donor dan ovum dari isteri, lalu embrionya ditransplantasikan ke dalam rahim isteri;

e. Bayi tabung yang menggunakan sperma dari donor dan ovum dari isteri, lalu embrionya ditransplantasikan ke dalam rahim ibu pengganti (surrogate mother);

f. Bayi tabung yang menggunakan sperma dari suami dan ovum dari donor, lalu embrionya ditransplantasikan ke dalam rahim ibu pengganti (surrogate mother);

g. Bayi tabung yang menggunakan sperma dan ovum dari donor yang kemudian embrionya ditransplantasikan ke dalam rahim isteri;

h. Bayi tabung yang menggunakan sperma dan ovum dari donor yang kemudian embrionya ditransplantasikan ke dalam rahim ibu pengganti (surrogate mother);

\footnotetext{
${ }^{8}$ Husni Thamrin, op.cit, hlm. 13

${ }^{9}$ Ibid, hlm.13-14
} 
Ada beberapa alasan pasangan suami isteri melakukan program bayi tabung untuk mendapatkan keturunan, yaitu $:^{10}$

1) Isteri mengalami kerusakan pada kedua saluran telur (tuba), biasanya disebabkan infeksi.

2) Lendir leher rahim yang tidak normal, hal ini terjadi biasaya bila ada keputihan, sehingga pada saat sperma melewati serviks, spermanya mati terlebih dahulu.

3) Masalah pada endometriosis pada rahim isteri

4) Masalah oligospermia pada suami, yaitu keadaan sperma yang jumlahnya kurang, gerakannya yang lemah, dan bentukanya juga tidak normal.

5) Unexplained infertility (tidak diketahui penyebabnya).

Namun dalam perkembangan selanjutnya, alasan menggunaan rahim ibu pengganti (surrogate mother) telah bergeser menjadi salah satu jalan bagi pasangan transgender atau pasangan sejenis untuk mendapatkan keturunan. Selain itu surrogate mother juga digunakan oleh wanita-wanita single yang tidak ingin terikat dalam perkawinan, namun ingin mempunyai keturunan dengan cara memanfaatkan bank sperma dan meminjam rahim wanita untuk menampung embrio hasil pembuahan ovumnya dan sperma dari bank sperma.

Contoh pasangan sejenis yang menggunakan rahim ibu pengganti (surrogate mother) untuk mendapatkan keturunan adalah Ricky Martin dan pasangan Jwan Yosef. ${ }^{11}$ Sebelumnya Ricky Martin telah memiliki anak kembar Valentino dan Matteo, yang lahir dari rahim seorang surrogate mother atau ibu pengganti. Diduga kuat jika si kembar putra sulung Ricky Martin tersebut yang lahir pada Agustus 2008 itu adalah hasil pembuahan sperma Ricky

\footnotetext{
${ }^{10} \mathrm{https}: / /$ nakita.grid.id, diakses pada 28 Mei 2020

${ }^{11}$ https://www.kapanlagi.com, Ricky Martin dan Suaminya Jwan Yosef sambut kelahiran anak ke-4, diunggah pada Rabu, 30 Oktober 2019 11:08, diakses pada 31 Mei 2020
} 
dengan telur mantan kekasihnya, Rebecca de Alba. ${ }^{12}$ Namun kemudian Ricky martin membesarkan sendiri anak kembarnya tersebut. Setelah menikah dengan Jwan Yosef (yang merupakan pasangan sejenis) Ricky martin kembali menggunakan jasa Surrogate Mother untuk kembali memiliki anak.

Ada beberapa negara yang melegalkan praktik sewa rahim ini seperti Amerika Serikat, India, Thailand, Ukraina, dan Rusia. Biaya bervariasi antara satu negara dengan negara lain, dan juga bergantung pada jumlah siklus In Vitro Fertilization (IVF)/program kehamilan yang dibutuhkan, dan apakah diperlukan asuransi kesehatan. Families Through Surrogacy, organisasi surogasi nirlaba internasional, memperkirakan biaya rata-rata di berbagai negara: - US \$100.000 (sekitar 1,4 miliar rupiah). ${ }^{13}$

Ada beberapa contoh pesohor dunia yang menggunakan jasa surrogate mother untuk mendapatkan keturunan, dengan berbagai alasannya, seperti :

1. Pasangan Kim Kardashian dan Kayne West yang mempunyai anak ketiga dengan menggunakan jasa surrogate mother. Situs TMZ melaporkan, pasangan ini telah menyewa ibu pengganti dengan biaya US\$ 45.000 atau sekitar Rp 590 juta untuk periode 10 bulan. Mereka juga harus membayar deposit US\$ 68.850 atau lebih dari Rp 901 juta kepada agensi sebagai depositnya.Hal ini karena alasan kesehatan, dimana Kim dilaporkan mengidap placenta accreta. ${ }^{14}$ Selain anak ketiga tersebut, anak keempat Kim Kardashian dan Kanye West yang diberi nama Psalm Ye dikabarkan lahir lewat ibu pengganti atau sewa rahim (surrogate mother). Rata-rata

\footnotetext{
${ }^{12}$ https://www.cumicumi.com, Demi Dapat Momongan Kim Kardashian Hingga Istri Shah Rukh Khan Sewa-Rahim Ibu Pengganti, Dipublikasikan Jumat, 17 Mei 2019 21:30, diakses pada 30 Mei 2020

${ }^{13}$ https://wow.tribunnews.com,Deretan Negara Yang Melegalkan Program Sewa Rahim Biayanya Fantastis, Dipublikasikan 26 Desember 2017, diakses pada 30 Mei 2020

${ }^{14}$ https://health.detik.com, Idap Placenta Accreta Kim Kadarsih Sewa Rahim Untuk Anak Ketiga Dipublikasikan Kamis, 22 Jun 2017 05:14 WIB, Diakses 30 Mei 2020
} 
biaya yang dikeluarkan untuk sewa rahim di Amerika Serikat dan Eropa berkisar dari Rp2,2 miliar hingga Rp3,2 miliar. $^{15}$

2. Cristiano Ronaldo mendapat anak kembar yang lahir dari rahim ibu pengganti atau surrogate mother yang tinggal di Amerika Serikat, Juni 2017. Sepasang bayi kembar laki-laki dan perempuan itu diberi nama Mateo dan Eva. ${ }^{16}$

3. Putra ketiga Shah Rukh Khan (SRK), Abram Khan, lahir dari rahim seorang ibu pengganti yang kabarnya saudara jauh SRK sendiri. Alasannya karena sang istri, Gauri Khan, sulit hamil. ${ }^{17}$

4. Nicole Kidman dan Keith Urban menggunakan jasa surrogate mother untuk anak kedua mereka tahun 2010. Alasan karena Nicole mengalami kesulitan untuk hamil lagi. hingga memilih menggunakan jasa ibu pengganti. ${ }^{18}$

Di Indonesia sendiri, hingga hari ini belum ada penggunaan jasa ibu pengganti (surrogate mother) yang terekspos. Penggunaan surrogate mother ini sempat menjadi perbincangan publik saat Jeremy Teti. Ia berada dalam posisi mendukung gerakan LGBT dan menyatakan pasangan LGBT dapat memiliki anak dengan cara menyewa rahim. ${ }^{19}$

Dasar yuridis penyelenggaraan bayi tabung di Indonesia mengacu pada UU No.36 Tahun 2009 tentang Kesehatan. Selain itu pelaksanaan bayi tabung juga mengacu pada Peraturan Pemerintah No 61 Tahun 2014 tentang Kesehatan Reproduksi. Di dalam dua peraturan tersebut tidak terdapat definisi dari surrogate mother.

\footnotetext{
${ }^{15}$ https://health.detik.com, Mengenal ibu pengganti yang melahirkan anak ke-4 Kim Kadarsih, Di publikasikan Selasa, 11 Jun 2019 11:10 WIB, Diakses 30 Mei 2020

${ }^{16}$ https://www.cumicumi.com, Demi Dapat Momongan Kim Kardashian Hingga Istri Shah Rukh Khan Sewa-Rahim Ibu Pengganti, Dipublikasikan Jumat, 17 Mei 2019 21:30, diakses pada 30 Mei 2020

${ }^{17}$ https://www.cumicumi.com, Demi Dapat Momongan Kim Kardashian Hingga Istri Shah Rukh Khan Sewa-Rahim Ibu Pengganti, Dipublikasikan Jumat, 17 Mei 2019 21:30, diakses pada 30 Mei 2020

${ }^{18}$ https://www.cumicumi.com, Demi Dapat Momongan Kim Kardashian Hingga Istri Shah Rukh Khan Sewa-Rahim Ibu Pengganti, Dipublikasikan Jumat, 17 Mei 2019 21:30, diakses pada 30 Mei 2020

${ }^{19}$ https://tirto.id/risiko-praktik-titip-janin-ala-kim-kardashian-cDsi, dipublikasikan 19 Januari 2018, diakses 30 Mei 2020
} 
Menurut Desriza Ratman, surrogate mother adalah perjanjian antara seorang wanita yang mengikatkan diri melalui suatu perjanjian dengan pihak lain (suami-isteri) untuk menjadi hamil terhadap hasil pembuahan suami isteri tersebut yang ditanamkan ke dalam rahimnya, dan setelah melahirkan diharuskan menyerahkan bayi tersebut kepada pihak suami isteri berdasarkan perjanjian yang dibuat. Perjanjian ini lazim disebut gestational agreement. $^{20}$

Menurut Husni Thamrin, surrogate mother yang sering disebut rahim sewaan, dimana sperma dan ovum dari pasangan suami isteri yang diproses dalam tabung lalu dimasukan ke dalam rahim orang lain dan bukan ke rahim isteri. ${ }^{21}$ Senada dengan hal tersebut Menurut Salim HS dalam Fajar Bayu setiawan dkk, kontrak sewa rahim adalah perjanjian seorang wanita yang mengikatkan dirinya dengan pihak lain (suami isteri) untuk menjadi hamil dan setelah melahirkan menyerahkan anak atau bayi tersebut. ${ }^{22}$

Pasal 1 angka 10 PP No. 61 Tahun 2014, hanya dijelaskan mengenai definisi dari Reproduksi dengan Bantuan atau Kehamilan di Luar Cara Alamiah adalah upaya memperoleh kehamilan di luar cara alamiah tanpa melalui proses hubungan seksual antara suami dan istri apabila cara alami tidak memperoleh hasil. Termasuk dalam kategori reproduksi dengan bantuan ini adalah program bayi tabung.

Bagaimana peraturan perundang-undangan di Indonesia mengatur mengenai program bayi tabung? Apabila merujuk pada UU No.36 Tahun 2009 tentang Kesehatan dan Peraturan Pemerintah No 61 Tahun 2014 tentang Kesehatan Reproduksi, pelaksanaan program bayi tabung diperbolehkan untuk dilakukan namun dengan beberapa ketentuan dan pembatasan dalam pelaksanaanya. Di dalam UU No.36 Tahun 2009 tentang kesehatan yaitu pada pasal 74

\footnotetext{
${ }^{20}$ Desriza Ratman, Surrogate Mother dalam Perspektif Etika dan Hukum: Bolehkah Sewa Rahim di Indonesia?, Elex Media Komputindo, Jakarta, 2012, hlm.3

${ }^{21}$ Husni Thamrin, op.cit, hlm.44

${ }^{22}$ Fajar Bayu Setiawan, Kedudukan Kontrak sewa rahim dalam hukum positif indonesia, jurnal Privat Law, edisi 01 Maret-Juni 2013
} 
dijelaskan bahwa pelaksanaan reproduksi dengan bantuan (termasuk di dalamnya program bayi tabung) boleh dilaksanakan asalkan tidak bertentangandengan nilai agama dan ketentuan peraturan perundang-undangan.

Di dalam PP No.61 tahun 2014, Program bayi tabung dapat dikategorikan sebagai "pelayanan reproduksi dengan bantuan atau kehamilan di luar cara alamiah". Pasangan suami isteri yang ingin menggunakan pelayanan Reproduksi dengan Bantuan atau Kehamilan di Luar Cara Alamiah harus memenuhi persyaratan meliputi: ${ }^{23}$

a. telah dilakukan pengelolaan infertilitas dengan tepat;

b. terdapat indikasi medis;

c. memahami prosedur konsepsi buatan secara umum;

d. mampu/cakap memberikan persetujuan tindakan kedokteran (informed consent);

e. mampu membiayai prosedur yang dijalani;

f. mampu membiayai persalinan dan membesarkan bayinya; dan

g. cakap secara mental.

Selain persyaratan tersebut di atas, pasangan suami isteri yang akan menggunakan pelayanan Reproduksi dengan Bantuan atau Kehamilan di Luar Cara Alamiah harus memperhatikan beberapa hal yaitu $:^{24}$

1) Pelayanan Reproduksi dengan Bantuan atau Kehamilan di Luar Cara Alamiah harus didahului dengan konseling dan persetujuan tindakan kedokteran (informed consent).

2) Konseling dan persetujuan tindakan kedokteran tersebut termasuk pengelolaan lebih lanjut terhadap kelebihan embrio. Alamiah

${ }^{23}$ Pasal 41 PP No.61 Tahun 2014 tentang Reproduksi dengan Bantuan atau Kehamilan di Luar Cara

${ }^{24}$ Pasal 42 PP No.61 Tahun 2014 tentang Reproduksi dengan Bantuan atau Kehamilan di Luar Cara Alamiah 
3) Konseling harus dilakukan sebelum dan sesudah mendapatkan pelayanan Reproduksi dengan Bantuan atau Kehamilan di Luar Cara Alamiah.

4) Konseling dilakukan oleh tenaga yang memiliki kompetensi dan kewenangan.

5) Persetujuan tindakan kedokteran (informed consent) dilaksanakan sesuai dengan ketentuan peraturan perundang-undangan.

Berkaitan dengan segi adminstrasi dari pelaksanaan Reproduksi dengan Bantuan atau Kehamilan di Luar Cara Alamiah terdapat beberapa ketentuan yang harus dipatuhi, yaitu: ${ }^{25}$

1. Pelayanan Reproduksi dengan Bantuan atau Kehamilan di Luar Cara Alamiah harus dilaksanakan di fasilitas pelayanan kesehatan yang memenuhi persyaratan, standar, dan memiliki izin dari Menteri.

2. Setiap fasilitas pelayanan kesehatan yang memberikan pelayanan Reproduksi dengan Bantuan atau Kehamilan di Luar Cara Alamiah wajib membuat pencatatan dan pelaporan kepada dinas kesehatan kabupaten/kota dengan tembusan dinas kesehatan provinsi.

3. Setiap pencatatan dan pelaporan tersebut dilakukan oleh fasilitas pelayanan kesehatan sesuai dengan ketentuan peraturan perundang-undangan.

Bagaimana dengan surrogate mother dalam hukum positif di Indonesia, apakah peraturan perundang-undangan di Indonesia telah memperbolehkannya sebagaimana undangundang tidak melarang program bayi tabung. Apabila merujuk pada ketentuan UU No.36 Tahun 2009 tentang Kesehatan dan Peraturan Pemerintah No 61 Tahun 2014 tentang Kesehatan Reproduksi secara tersirat disebutkan bahwa penggunaan rahim sewaan dalam program bayi tabung dilarang.

${ }^{25}$ Pasal 45-46 PP No.61 Tahun 2014 tentang Reproduksi dengan Bantuan atau Kehamilan di Luar Cara 
Dalam Pasal 127 UU Kesehatan diatur bahwa upaya kehamilan di luar cara alamiah hanya dapat dilakukan oleh pasangan suami istri yang sah dengan ketentuan:

1) hasil pembuahan sperma dan ovum dari suami istri yang bersangkutan ditanamkan dalam rahim istridari mana ovum berasal;

2) dilakukan oleh tenaga kesehatan yang mempunyai keahlian dan kewenangan untuk itu;

3) pada fasilitas pelayanan kesehatan tertentu.

Dari ayat (1) pasal 127 di atas jelas tersirat, bahwa program tabung sebagai salah satu bentuk upaya kehamilan di luar cara alamiah hanya dapat dilakukan bila embrio hasil pembuahan sperma dan ovum suami isteri ditanamkan ke dalam rahim isteri pemilik ovum. Sehingga dengan menggunakan penafsiran hukum secara argumentum a contrario, maka apabila embrio hasil pembuahan di tanamkan ke dalam rahim wanita lain, bukan isteri pemilik ovum berasal maka tersebut terlarang atau tidak diperbolehkan. ${ }^{26}$

Selanjutnya di dalam Pasal 40 PP No.61 Tahun 2014 disebutkan Reproduksi dengan Bantuan atau Kehamilan di Luar Cara Alamiah hanya dapat dilakukan pada pasangan suami isteri yang terikat perkawinan yang sah dan mengalami ketidaksuburan atau infertilitas untuk memperoleh keturunan. Reproduksi dengan Bantuan atau Kehamilan di Luar Cara Alamiah ini dilaksanakan dengan menggunakan hasil pembuahan sperma dan ovum yang berasal dari suami istri yang bersangkutan dan ditanamkan dalam rahim istri dari mana ovum berasal.

Selain itu apabila kita merujuk pada aturan hukum perjanjian pada KUHPerdata. Dalam pasal 1320 syarat sah suatu perjanjian diperlukan empat syarat:

\footnotetext{
${ }^{26}$ Menurut Sodikno Mertokusumo, dalam bukunya Bab-bab tentang Penemuan Hukum, argumentum a contrario adalah cara menemukan hukum dengan pertimbangan bahwa apabila undang-undang menetapkan halhal tertentu untuk peristiwa tertentu, maka peraturan itu terbatas pada peristiwa tertentu itu dan untuk peristiwa di luarya berlaku kebalikannya.
} 
a. Adanya kesepakatan mereka yang mengikatkan diri;

Para pihak yang mengadakan perjanjian harus sepakat, setuju dan seia sekata dalam hal pokok daripada perjanjian yang akan diadakan tersebut. Kata sepakat tersebut dapat batal apabila terdapat unsur-unsur penipuan, paksaan dan kekhilafan. Dalam pasal 1321 KUHPer dinyatakan bahwa tiada sepakat yang sah apabila sepakat itu diberikan secara kekhilafan atau diperolehnya dengan paksaan/penipuan. ${ }^{27}$

b. Kecakapan untuk melakukan perbuatan hukum;

Sebagai lawan dari cakap hukum (syarat kecakapan) adalah tidak cakap hukum, hal ini diatur dalam Pasal 1330 KUHPer. Dari Pasal 1330 KUHPer itu terdapat pengertian tidak cakap dalam 2 (dua) hal, yaitu: ${ }^{28}$

1) Orang di bawah umur adalah orang yang belum kawin dan belum berumur 21 tahun.

2) Orang yang di bawah pengampuan (curatele) yaitu orang yang sudah dewasa atau telah berumur di atas 21 tahun tetapi tidak mampu karena pemabuk, gila dan pemboros.

c. Suatu hal tertentu;

Suatu perjanjian harus mengenai hal tertentu artinya apa yang diperjanjikan hak-hak dan kewajiban kedua belah pihak jika timbul suatu perselisihan. barang yang dimaksud dalam perjanjian paling sedikit harus ditentukan jenisnya. Bahwa barang itu sudah ada atau sudah berada di tangannya si berutang pada waktu perjanjian dibuat tidak

\footnotetext{
${ }^{27}$ Elsi Kartika Sari dan Advendi Simanungsong, Hukum dalam Ekonomi, PT.Gramedia Widiasarana Indonesia, Jakarta, 2005, hlm.28

${ }_{28}$ C.S.T.Kansil dan Christine S.T.Kansil, Modul Hukum Perdata Termasuk Asas-Asas Hukum Perdata, Pradnya Paramitha, Jakarta. 2000 hlm.225
} 
diharuskah oleh undang-undang. Juga jumlahnya tidak perlu disebutkan, asal saja kemudian dapat dihitung atau ditetapkan. ${ }^{29}$

d. suatu sebab yang halal.

Pasal 1320 KUHPer tidak dijelaskan pengertian orzaak (causa yang halal). Di dalam Pasal 1337 KUHPer hanya disebutkan causa yang terlarang. Suatu sebab adalah terlarang apabila bertentangan dengan Undang-Undang, Kesusilaan dan ketertiban umum.

Perjanjian sewa rahim ibu pengganti (surrogate mother) tidak memenuhi syarat sah suatu sebab yang halal, karena perjanjian sewa rahim ibu pengganti (surrogate mother) dilarang di dalam UU No.36 Tahun 2009 tentang Kesehatan dan Peraturan Pemerintah No 61 Tahun 2014 tentang Kesehatan Reproduksi. Sehingga akibatnya batal demi hukum.

Dalam proses pelaksanaan program bayi tabung mungkin saja terjadi kelebihan embrio hasil pembuahan di luar tubuh manusia (ferlilisasi invitro) yang tidak ditanamkan pada rahim isteri. Bagaimana keberadaan embrio yang lebih ini? PP No.61 Tahun 2014 memberikan beberapa pengaturan, bahwa:

1) Kelebihan embrio hasil pembuahan di luar tubuh manusia (ferlilisasi invitro) yang tidak ditanamkan pada rahim harus disimpan sampai lahirnya bayi hasil Reproduksi dengan Bantuan atau Kehamilan di Luar Cara Alamiah.

2) Penyimpanan kelebihan embrio tersebut dapat diperpanjang setiap 1 (satu) tahun atas keinginan pasangan suami istri untuk kepentingan kehamilan berikutnya.

3) Kelebihan embrio tersebut dilarang ditanam pada:

a. rahim ibu jika ayah embrio meninggal atau bercerai; atau

b. rahim perempuan lain.

${ }^{29}$ Subekti,Aneka Perjanjian, PT.Citra Aditya Bakti, Bandung 1996, hlm.141 
4) Dalam hal pasangan suami istri pemiliknya tidak memperpanjang masa simpan kelebihan embrio, fasilitas pelayanan kesehatan penyelenggara Reproduksi dengan Bantuan atau Kehamilan di Luar Cara Alamiah harus memusnahkan kelebihan embrio.

Hal ini untuk mencegah hal-hal yang tidak dinginkan. Karena embrio merupakan hasil dari pertemuan dari sperma dan sel telur dari pasangan suami isteri maka jangan sampai kemudian embrio ini menimbulkan permasalahan dikemudian hari apabila ditanamkan di rahim perempuan lain, atau masih ditanamkan ke rahim isteri sementara suami telah meninggal dunia atau pasangan suami isteri ini telah bercerai.

Apa sanksi yang diberikan apabila pasangan suami isteri menggunakan rahim ibu pengganti dalam program bayi tabung? Di dalam UU No.36 Tahun 2009 tentang kesehatan tidak terdapat sanksi apabila terjadi pelanggaran pasal 127 ayat (1). Namun di dalam PP No.61 Tahun 2014 dalam pasal 51 disebutkan mengenai sanksi dari pelanggaran pasal 40 mengenai penggunaan rahim sewaan (surrogate mother) dalam program bayi tabung, yaitu tindakan administratif terhadap tenaga kesehatan dan fasilitas pelayanan kesehatan. Tindakan administrasinya berupa :

a. teguran tertulis;

b. denda administratif;

c. pencabutan izin sementara; dan/atau

d. pencabutan izin tetap.

Tidak terdapat sanksi hukum bagi suami isteri yang mempunyai sperma dan ovum serta tidak ada juga sanksi hukum bagi wanita yang menyediakan rahim. Sanksi hukum hanya diberikan kepada tenaga kesehatan dan fasilitas pelayanan kesehatan yang menyelenggarakan program bayi tabung dengan menggunakan rahim ibu pengganti (surrogate mother). 
Di larangnya penggunaan rahim ibu pengganti dalam program bayi tabung di Indonesia dapat dipahami karena memang penggunaan rahim ibu pengganti ini lebih banyak sisi negatifnya ketimbang sisi positifnya. Akan ada beberapa permasalahan yang nantinya akan timbul dari penggunaan rahim ibu pengganti dalam program bayi tabung, diantaranya :

a. Mengenai status anak yang dilahirkan dari rahim ibu pengganti. Apakah merupakan anak sah dari pasangan suami isteri pemiliki sperma dan ovum ataukah anak sah dari ibu pengganti.

b. Mengenai hak waris dari si anak. Apakah si anak berhak mendapatkan waris dari ibu yang mengandungnya, atau mewaris dari ayah ibu biologisnya?

c. Permasalahan psikologis anak. Terutama apabila penggunaan rahim sewaan ini dilakukan oleh pasangan sejenis. Tentu akan menimbulkan kebingungan bagi si anak.

d. Akan menimbulkan permasalahan hukum juga nantinya apabila si ibu yang rahimnya disewa tidak mau menyerahkan anak yang dilahirkannya dari perjanjian surrogate mother.

e. Selain itu dalam hukum Islam, nantinya akan menimbulkan permasalahan nasab si anak.

f. Dan lain-lain permasalahan lainnya yang akan timbul, baik secara etika, agama dan norma adat yang ada di Indonesia.

\section{Penutup}

1. Program bayi tabung di Indonesia diperbolehkan namun dengan ketentuan sperma dan ovum harus dari pasangan suami isteri dan embrio hasil pembuahan ditanamkan kerahim isteri, sebagaimana diatur di dalam UU No.36 Tahun 2009 tentang kesehatan dan PP No.61 Tahun 2014 Kesehatan Reproduksi. 
2. Penggunaan rahim ibu pengganti (surrogate mother) dilarang di Indonesia. Larangan itu terdapat dalam Pasal 127UU No.36 Tahun 2009 tentang kesehatan dan pasal 40 PP No.61 Tahun 2014.

3. Sanksi bagi pelaku penggunaan rahim ibu pengganti dalam program bayi tabung diberikan kepada tenaga medis dan fasilitas pelayanan kesehatan yang melaksanakan program bayi tabung yang memperbolehkan penggunaan surrogate mother. Sanksinya berupa sanksi administrasi. Sementara untuk suami isteri sebagai individu yang menggunakan jasa surrogate mother dan wanita sebagai surrogate mothernya itu sendiri tidak ada sanksi.

\section{DAFTAR PUSTAKA}

\section{Buku}

C.S.T.Kansil dan Christine S.T.Kansil, Modul Hukum Perdata Termasuk Asas-Asas Hukum Perdata, Pradnya Paramitha, Jakarta. 2000

Desriza Ratman, Surrogate Mother dalam Perspektif Etika dan Hukum: Bolehkah Sewa Rahim di Indonesia?, Elex Media Komputindo, Jakarta, 2012

Elsi Kartika Sari dan Advendi Simanungsong, Hukum dalam Ekonomi, PT.Gramedia Widiasarana Indonesia, Jakarta, 2005

Hilman Hadikusuma, Hukum Perkawinan Indonesia menurut Perundangan, hukum adat, hukum agama, Mandar Maju, Bandung, 2007

Husni Thamrin, Aspek Hukum Bayi Tabung dan Sewa Rahim : Perspektif Hukum Perdata dan Hukum Islam, Aswaja Pressindo, Yogyakarta, 2014

Idries, AM, Aspek Medikolegal Pada Inseminasi Buatan/Bayi Tabung, Ed.I, Jakarta, Binarupa Aksara.

Mukti Fajar ND dan Yulianto Achmand, 2013, Dualisme Penelitian Hukum Normatif dan Empiris, Yogyakarta; Pustaka Pelajar

PC. Steptoe dan R.G. Edwards, Birth After Reimplantation of Human Embryo, The Lancet, Vol II For 197 8, August 12, 1978

Subekti,Aneka Perjanjian, PT.Citra Aditya Bakti, Bandung 1996

Sudikno Mertokusumo dan A. Pitlo, Bab-bab Tentang Penemuan Hukum, PT. Citra Aditya Bakti, Yogyakarta, 2013

\section{Perundang-undangan}

Kitab undang-undang hukum perdata 
Undang-Undang Nomor 36 Tahun 2009 tentang kesehatan

Peraturan Pemerintah Nomor 61 Tahun 2014 Kesehatan Reproduksi.

\section{Lain-lain}

http://bayitabung-rsiafamily.com, diakses pada 28 Mei 2020

https://nakita.grid.id, diakses pada 28 Mei 2020

https://www.kapanlagi.com, Ricky Martin dan Suaminya Jwan Yosef sambut kelahiran anak ke-4, diunggah pada Rabu, 30 Oktober 2019 11:08, diakses pada 31 Mei 2020

https://www.cumicumi.com, Demi Dapat Momongan Kim Kardashian Hingga Istri Shah Rukh Khan Sewa-Rahim Ibu Pengganti, Dipublikasikan Jumat, 17 Mei 2019 21:30, diakses pada 30 Mei 2020

https://wow.tribunnews.com, Deretan Negara Yang Melegalkan Program Sewa Rahim Biayanya Fantastis, Dipublikasikan 26 Desember 2017, diakses pada 30 Mei 2020

https://health.detik.com, Idap Placenta Accreta Kim Kadarsih Sewa Rahim Untuk Anak Ketiga Dipublikasikan Kamis, 22 Jun 2017 05:14 WIB, Diakses 30 Mei 2020

https://tirto.id/risiko-praktik-titip-janin-ala-kim-kardashian-cDsi, dipublikasikan 19 Januari 2018, diakses 30 Mei 2020

Fajar Bayu Setiawan, Kedudukan Kontrak sewa rahim dalam hukum positif indonesia, jurnal Privat Law, edisi 01 Maret-Juni 2013 